\title{
KORELASI ANTARA KETERSEDIAAN LAPANGAN KERJA, SISTEM PENGUPAHAN DAN PEKERJAAN SEKTOR INFORMAL
}

\author{
Gindo L. Tobing ${ }^{1}$
}

\begin{abstract}
Labor issues in Indonesia is an issue that over the years have always not solved because of the amount of labor in comparison with job availability is not balanced. Besides the problem of limited employment, are compounded by the low wages of workers/laborers in our country. Wage system still uses the term minimum wage is not worth living needs. The informal sector and transmigration may be one solution for the provision of jobs.
\end{abstract}

\section{Kata kunci : Upah dan Pekerja Sektor Informal}

\section{PENDAHULUAN}

Pembangunan ekonomi ${ }^{2}$ sebagai usaha untuk meningkatkan taraf hidup suatu bangsa seringkali diukur dengan tinggi rendahnya pendapatan riil per kapita. Salah satu masalah ekonomi yang paling pokok adalah adanya ketidakseimbangan antara kebutuhan manusia yang tidak terbatas dengan alat pemuas kebutuhan yang jumlahnya terbatas. Permasalahan itu kemudian menyebabkan timbulnya kelangkaan ${ }^{3}$ (scarcity) sumber daya yang secara terus menerus dieksploitasi. ${ }^{4}$ Dengan demikian batasan hukum ekonomi sebagai suatu hubungan sebab akibat atau pertalian peristiwa ekonomi yang saling berhubungan satu dengan yang lain dalam kehidupan ekonomi sehari-hari dalam masyarakat ${ }^{5}$ menjadi bersesuaian dengan penjelasan di atas.

\footnotetext{
${ }^{1}$ Dosen Tetap Fakultas Hukum UKI.

${ }^{2}$ Tujuan pembangunan ekonomi disamping untuk menaikkan pendapatan nasional riil juga untuk meningkatkan produktifitas artinya tingkat out put pada suatu saat tertentu ditentukan oleh tersedianya atau digunakannya baik sumberdaya alam maupun sumber daya manusia, teknologi, keadaan pasar kerangka kehidupan ekkonomi (sistem perekonomian) serta sikap dari out put itru sendiri, baca: Irawan dan M. Suparmoko, Ekonomika Pembangunan, Edisi 5,Yogyakarta: BPFE, 1995, hal. 5

${ }^{3}$ Bandingkan dengan mineral dan batu bara sebagai kekayaan alam yang terkandung di dalam bumi merupakan sumber daya alam yang tidak terbarukan, maka pengelolaannya harus seoptimal mungkin, efisien, transparan, berkelanjutan dan berwawasan lingkungan serta berkeadilan untuk sebesar-besarnya kemakmuran rakyat secara berkelanjutan, baca: Adrian Sutedi, Hukum Pertambangan, Jakarta: Sinar Grafika, 2012, hal. 104.

${ }^{4}$ Eksploitasi sebagai rangkaian kegiatan yang bertujuan untuk menghasilkan minyak dan gas bumi pada suatu wilayah kerja tertentu, sejak pengeboran, penyelesaian sumur, pembangunan sarana pengangkutan, penyimpanan dan pengelolaan, op. cit, hal. 70

5 http://hukum-on.blogspot.com/2012/06/pengertian-ekonomi-danhukum-ekonomi.html (diunduh tanggal 13 Mei 2013)
}

Rumusan lain hukum ekonomi juga oleh Sanu- si Bintang dan Dahlan ${ }^{6}$ adalah seluruh peraturan dan pemikiran hukum mengenai cara-cara peningkatan dan pengembangan kehidupan ekonomi dan caracara pembagian hasil pembangunan ekonomi seca- ra adil dan merata sesuai dengan hak asasi manusia. Peningkatan dan pengembangan kehidupan ekonomi salah satu unsur terpenting dan terutama disitu adalah faktor sumber daya manusianya. ${ }^{7}$ Atau pembangunan ekonomi tidak dapat dipisahkan dari peran serta manusia sebagai penggerak pembangunan tersebut atau faktor manusia adalah salah satu unsur/faktor pokok yang sangat menentukan maju mundurnya suatu pembangunan di sektor apa pun.

Pembangunan ekonomi ${ }^{8}$ adalah suatu proses kenaikan pendapatan total dan pendapatan perkapita dengan memperhitungkan adanya pertambahan penduduk dan disertai dengan perubahan fundamental dalam struktur ekonomi suatu negara dan pemerataan pendapatan bagi penduduk suatu negara. Pembangunan ekonomi tak dapat lepas dari pertumbuhan ekonomi (economic growth), pembangunan ekonomi

\footnotetext{
${ }^{6}$ Sanusi Bintang dan Dahlan, Pokok-Pokok Hukum Ekonomi dan Bisinis, Bandung,: Citra Aditya Bakti, 2000, hal. 3.

${ }^{7}$ Dalam suatu proses produksi ada tiga faktor produksi yang dikonbinasikan dalam jumlah dan kualitas yang tertentu, yaitu faktor produksi tenaga kerja, modal dan bahan mentah. Dalam ekonomi mikro tenaga kerja disebut sebagai faktor produksi yang bersifat variabel (variable input) artinya faktor produksi varabel dapat diubah-ubah dalam waktu yang relatif singkat sesuai dengan jumlah out put yang dihasilkan, baca: Ari Sudarman, Teori Ekonomi Mikro, Yogyakarta:BPFE, 2011, hal. 105-106.

${ }^{8}$ http://id.wikipedia.org/wiki/Pembangunan_ekonomi (diunduh tanggal 13 Mei 2013)
} 
mendorong pertumbuhan ekonomi, dan sebaliknya, pertumbuhan ekonomi memperlancar proses pembangunan ekonomi.

Antara pembangunan ekonomi dan pertumbuhan ekonomi ${ }^{9}$ terdapat perbedaan dimana pengertian pertumbuhan ekonomi adalah proses kenaikan kapasitas produksi suatu perekonomian yang diwujudkan dalam bentuk kenaikan pendapatan nasional. Suatu negara dikatakan mengalami pertumbuhan ekono- mi apabila terjadi peningkatan GNP riil di negara tersebut. ${ }^{10}$ Adanya pertumbuhan ekonomi merupakan indikasi keberhasilan pembangunan ekonomi. Selanjutnya pembangunan ekonomi diartikan sebagai suatu proses yang menyebabkan pendapatan perkapita penduduk meningkat dalam jangka panjang. Di sini terdapat tiga elemen penting yang berkaitan dengan pembangunan ekonomi. ${ }^{11}$

\section{a. Pembangunan sebagai suatu proses}

Pembangunan sebagai suatu proses, artinya bahwa pembangunan merupakan suatu tahap yang harus dijalani oleh setiap masyarakat atau bangsa. Sebagai contoh, manusia mulai lahir, tidak langsung menjadi dewasa, tetapi untuk menjadi dewasa harus melalui tahapan-tahapan pertumbuhan. Demikian pula, setiap bangsa harus menjalani tahap-tahap perkembangan untuk menuju kondisi yang adil, makmur, dan sejahtera.

\section{b. Pembangunan sebagai suatu usaha untuk me- ningkatkan pendapatan perkapita}

Sebagai suatu usaha, pembangunan merupakan tindakan aktif yang harus dilakukan oleh suatu negara dalam rangka meningkatkan pendapatan perkapita. Dengan demikian, sangat dibutuhkan peran serta masyarakat, pemerintah, dan semua elemen yang terdapat dalam suatu negara untuk berpartisipasi aktif dalam proses pembangunan. Hal ini dilakukan karena kenaikan pendapatan perkapita mencerminkan perbaikan dalam kesejahteraan masyarakat.

\section{c. Peningkatan pendapatan perkapita harus ber- langsung dalam jangka panjang}

Suatu perekonomian dapat dinyatakan dalam keadaan berkembang apabila pendapatan perkapita

\footnotetext{
${ }^{9}$ Ibid, http://id.wikipedia.org/wiki/Pembangunan_ekonomi

${ }^{10}$ Bannock, Graham, R. E. Baxter dan Evan Davis. 2004. A Dictionary of Economics. Inggris: Penguin Books Ltd

${ }^{11} \mathrm{http}$ ///id.wikipedia.org/wiki/Pembangunan_ekonomi op.cit
}

dalam jangka panjang cenderung meningkat. Hal ini tidak berarti bahwa pendapatan perkapita harus mengalami kenaikan terus menerus, misalnya, suatu negara terjadi musibah bencana alam ataupun kekacauan politik, maka mengakibatkan perekonomian negara tersebut mengalami kemunduran. Namun, kondisi tersebut hanyalah bersifat sementara yang terpenting bagi negara tersebut kegiatan ekonominya secara rata-rata meningkat dari tahun ke tahun.

Pembangunan ekonomi yang berlangsung di suatu negara membawa dampak, baik positif maupun negatif.

\section{Dampak Positif Pembangunan Ekonomi}

1. Melalui pembangunan ekonomi, pelaksanaan kegiatan perekonomian akan berjalan lebih lancar dan mampu mempercepat proses pertumbuhan ekonomi.

2. Adanya pembangunan ekonomi dimungkinkan terciptanya lapangan pekerjaan yang dibutuhkan oleh masyarakat, dengan demikian akan mengurangi pengangguran.

3. Terciptanya lapangan pekerjaan akibat adanya pembangunan ekonomi secara langsung bisa memperbaiki tingkat pendapatan nasional.

4. Melalui pembangunan ekonomi dimungkinkan adanya perubahan struktur perekonomian dari struktur ekonomi agraris menjadi struktur ekonomi industri, sehingga kegiatan ekonomi yang dilaksanakan oleh negara akan semakin beragam dan dinamis.

5. Pembangunan ekonomi menuntut peningkatan kualitas SDM sehingga dalam hal ini, dimungkinkan ilmu pengetahuan dan teknologi akan berkembang dengan pesat. Dengan demikian, akan makin meningkatkan kesejahteraan masyarakat.

\section{Dampak Negatif Pembangunan Ekonomi}

1. Adanya pembangunan ekonomi yang tidak terencana dengan baik mengakibatkan adanya kerusakan lingkungan hidup.

2. Industrialisasi mengakibatkan berkurangnya lahan pertanian.

3. Hilangnya habitat alam baik hayati atau hewani

Adanya pembangunan ekonomi dimungkinkan terciptanya lapangan pekerjaan yang dibutuhkan oleh masyarakat, dengan demikian akan mengurangi pengangguran. Terciptanya lapangan pekerjaan akibat 
adanya pembangunan ekonomi secara langsung bisa memperbaiki tingkat pendapatan nasional. Rangkaian yang saling mempengaruhi ini tidak serta merta memperbaiki tingkat pendapatan kaum pekerja/buruh karena upah yang diterima pekerja/buruh belum cukup memadai untuk menopang kehidupan si pekerja/buruh dan keluarganya dalam arti belum dapat hidup layak apabila aspek pendidikan, kesehatan dan perumahan yang menjadi tolok ukurnya. Di bawah ini tersaji besaran Upah Minimum Provinsi (UMP) di 29 provinsi

\section{UMP di 29 Provinsi Indonesia tahun $\mathbf{2 0 1 5}^{\mathbf{1 2}}$} (dalam rupiah)

\begin{tabular}{|l|l|c|c|}
\hline No & \multicolumn{1}{|c|}{ Provinsi } & UMP & $\begin{array}{c}\text { Kenaikan } \\
(\boldsymbol{\%})\end{array}$ \\
\hline 1 & Aceh & 1.900 .000 & 8,57 \\
\hline 2 & Sumatera Utara & 1.625 .000 & 7,10 \\
\hline 3 & Sumatera Barat & 1.615 .000 & 8,39 \\
\hline 4 & Riau & 1.878 .000 & 10,47 \\
\hline 5 & Kepulauan Riau & 1.954 .000 & 17,36 \\
\hline 6 & Jambi & 1.710 .000 & 13,83 \\
\hline 7 & Sumatera Selatan & 1.974 .346 & 8,15 \\
\hline 8 & Bangka Belitung & 2.100 .000 & 28,05 \\
\hline 9 & Bengkulu & 1.500 .000 & 11,11 \\
\hline 10 & Lampung & 1.581 .000 & 13,01 \\
\hline 11 & Banten & 1.900 .000 & 8,57 \\
\hline 12 & Bali & 1.621 .172 & 5,09 \\
\hline 13 & DKI Jakarta & 2.700 .00 & 10,6 \\
\hline 14 & Nusa Tenggara Barat & 1.330 .000 & 9,92 \\
\hline 15 & NTB) & & \\
\hline 16 & Kusa Tenggara Timur & 1.250 .000 & 8,7 \\
\hline 17 & Kalimantan Selatan & 1.870 .000 & 15,43 \\
\hline 18 & Kalimantan Tengah & 1.896 .367 & 10,00 \\
\hline 19 & Kalimantan Timur & 2.026 .126 & 7,41 \\
\hline 20 & Gorontalo & 1.600 .000 & 20,75 \\
\hline 21 & Sulawesi Utara & 2.150 .000 & 13,16 \\
\hline 22 & Sulawesi Tenggara & 1.652 .000 & 18,00 \\
\hline 23 & Sulawesi Tengah & 1.500 .000 & 20,00 \\
\hline 24 & Sulawesi Selatan & 2.000 .000 & 11,11 \\
\hline 25 & Sulawesi Barat & 1.655 .500 & 18,25 \\
\hline 26 & Maluku & 1.650 .000 & 16,61 \\
\hline 27 & Maluku Utara & 1.577 .000 & 9,50 \\
\hline 28 & Papua & 2.193 .000 & 7,50 \\
\hline 29 & Papua Barat & & \\
\hline
\end{tabular}

\footnotetext{
${ }^{12}$ Ditjen PHI dan Jamsostek
}

di Indonesia yang secara sederhana akan menggambarkan bagaimana tingkat kesejahteraan pekerja/buruh dan keluarganya dibandingkan dengan besaran penghasilan tersebut (lihat tabel UMP di 29 Provinsi).

Berdasarkan tabel tersebut di atas dapat disimpulkan sementara bahwa pembangunan ekonomi tidak berbanding lurus dengan tingkat kesejahteraan buruh/pekerja melalui upah yang diterima setiap bulan (apabila didasarkan pada pengertian pembangunan ekonomi di atas). Upah yang diterima hanya cukup untuk kebutuhan makan untuk beberapa minggu saja sementara kebutuhan akan kesehatan dan pendidikan tidak mungkin terjangkau hanya mengandalkan upah sebesar itu. Atau dengan kata lain upah buruh masih dengan perhitungan minimal (UM) tidak berdasarkan kebutuhan hidup yang layak (KHL).

Walaupun tingkat upah masih tergolong rendah tetapi karena jumlah lapangan kerja yang tersedia terbatas akibat jumlah pengangguran sebagaima- na dilansir oleh Jakarta.kompas.com ${ }^{13}$ Senin, 6 Mei 2013. Juga Badan Pusat Statistik (BPS) mencatat angka pengangguran di Indonesia hingga Februari 2013 mengalami penurunan menjadi 7,17 juta orang dibanding Agustus 2012 yang mencapai 7,24 juta orang artinya tingkat pengangguran di Indonesia masih tinggi walaupun terjadi perbaikan ekonomi sehingga menimbulkan dampak positif bagi pertumbuhan industri.

Ternyata keadaan tahun 2013 tersebut terulang kembali pada tahun 2014 sebagaimana dilansir oleh Menteri Ketenagakerjaan M. Hanif Dhakiri ${ }^{14}$ mengatakan berdasarkan data Badan Pusat Statistik (BPS) Agustus 2014 jumlah pengangguran terbuka di Indonesia mencapai 7,24 juta orang. "Tingkat pengangguran terbuka tersebut menunjukkan kenaikan jika dibandingkan Februari 2014, di mana jumlah penganggur terbuka sebanyak 7,15 juta orang," katanya pada peresmian Padat Karya Pembangunan Jembatan Gantung Berbasis Sumberdaya Lokal di Desa Slukatan, Kecamatan Mojotengah, Kabupaten Wonosobo, Kamis (15 Januari 2015). Menurut Menaker kenaikan tingkat pengangguran tersebut harus diwaspadai karena berpotensi menjadi ancaman ledakan pengan-

\footnotetext{
13 http://bisniskeuangan.kompas.com/read/2013/05/06/15031042/ Turun.Tipis.Angka.Pengangguran.di Indonesia.Capai.7.17.Juta. Orang (diunduh tanggal 13 Mei 2013)

${ }^{14} \mathrm{http} / / /$ nasional.kontan.co.id/news/jumlah-pengangguran-terbukaindonesia-724-juta (diunduh tanggal 30 Juni 2013)
} 
gguran di tengah krisis ekonomi global dan terjadinya bonus demografi di Indonesia.

Menaker mengatakan upaya penanggulangan pengangguran merupakan pekerjaan yang kompleks. Oleh karena itu, implementasi program perluasan kesempatan kerja sektor informal harus dilaksanakan secara sinergi dan terintegrasi dengan melibatkan stake holder terkait, yaitu pemerintah pusat dan daerah, para pelaku usaha serta kelompok masyarakat sehingga program-program tersebut nantinya dapat memberikan hasil yang optimal bagi pembangunan ekonomi masyarakat pedesaan.

Melambatnya pergerakan roda ekonomi membawa dampak bagi sektor ketenagakerjaan Indonesia. Badan Pusat Statistik (BPS) mencatat dalam kurun waktu satu tahun tingkat pengangguran di Indonesia mengalami pertambahan sebanyak 300 ribu jiwa.

Kepala BPS Suryamin mengatakan jumlah pengangguran pada Februari 2015 mengalami peningkatan dibandingkan dengan Agustus 2014 sebanyak 210 ribu jiwa. Sementara jika dibandingkan dengan Februari tahun lalu bertambah 300 ribu jiwa.

Suryamin pada konferensi pers di Jakarta, Selasa 5 Mei 2015 menjelaskan jumlah pengangguran pada Februari 2015 mencapai 7,4 juta orang, dengan tingkat pengangguran terbuka (TPT) yang mengalami kenaikan untuk tingkat pendidikan tinggi. "Ini karena ekonomi melambat, sehingga terjadi peningkatan pengangguran," ujarnya. Berdasarkan data BPS, pengangguran untuk lulusan strata satu (S1) pada Februari 2015 menjadi 5,34 persen dibanding Februari tahun lalu yang hanya 4,31 persen. Begitu juga lulusan diploma mengalami peningkatan pengangguran dari 5,87 persen menjadi 7,49 persen. Serta pengangguran lulusan SMK yang bertambah dari 7,21 persen menjadi 9,05 persen. Sementara untuk tingkat pendidikan SD, SMP, dan SMA mengalami penurunan, masing- masing yakni dari 3,69 persen menjadi 3,61 persen, 7,44 persen jadi 7,14 persen, dan 9,10 persen menjadi 8,17 persen. "Februari 2015, TPT terendah ada pada penduduk berpendidikan SD ke bawah dan tertinggi pada jenjang pendidikan SMK, diikuti diploma dan universitas." Secara persentase, tingkat pengangguran terbuka (TPT) pada Februari 2015 sebesar 5,81 persen, meningkat dibandingkan dengan periode yang sama tahun lalu 5,7 persen. Namun, angka tersebut lebih rendah jika dibandingkan dengan TPT Agustus 2014 yang sebesar 5,94 persen. Suryamin menjelaskan perubahan tingkat pengangguran di Indonesia terjadi selaras dengan bertambahnya jumlah angkatan kerja yang sebanyak 3 juta orang dibandingkan dengan Februari 2014 atau sebanyak 6,4 juta orang jika dibandingkan dengan posisi Agustus 2014. Sayangnya, angka serapan tenaga kerjanya jauh lebih rendah yakni hanya 1 juta jiwa selama periode Februari 2014 - Februari 2015. Kendati pengangguran bertambah, Suryamin mengklaim jumlah penduduk yang bekerja pada Februari 2015 juga bertambah 6,2 juta orang dibanding keadaan Agustus 2014 atau bertambah 2,7 juta orang dibanding keadaan Februari 2014. Jumlah penduduk yang bekerja per-Februari 2015 tercatat sebanyak 120,8 juta orang. (lihat tabel Tenaga Kerja Indonesia)

Sementara dalam hal lapangan kerjanya, mayoritas masih dikontribusikan dari sektor pertanian, perdagangan, jasa kemasyarakatan, dan sektor industri yang menjadi kontributor terbesar penyerapan tenaga kerja di Indonesia. Sektor-sektor lain yang menjadi kontributor penyedia lapangan kerja ini antara lain sektor perdagangan (naik 3,29 persen), sektor konstruksi naik 12,95 persen, dan sektor industri naik 4,01 persen. "Sementara sektor-sektor yang mengalami penurunan adalah sektor pertanian dan lainnya yang masing-masing mengalami penurunan 3,01 persen dan 5,73 persen.

Tenaga Kerja Indonesia:

\begin{tabular}{|l|r|r|r|r|r|}
\hline & \multicolumn{1}{|c|}{2010} & \multicolumn{1}{c|}{2011} & \multicolumn{1}{c|}{2012} & \multicolumn{1}{c|}{2013} & \multicolumn{1}{c|}{2014} \\
\hline Tenaga Kerja & $116,527,546$ & $119,399,375$ & $120,320,000$ & $120,170,000$ & $121,870,000$ \\
\hline - Bekerja & $108,207,767$ & $111,281,744$ & $113,010,000$ & $112,760,000$ & $114,630,000$ \\
\hline - Menganggur & $8,319,779$ & $8,117,631$ & $7,310,000$ & $7,410,000$ & $7,240,000$ \\
\hline & & & & & \\
\hline
\end{tabular}

Sumber: Badan Pusat Statistik 
Keterpaduan pembangunan di bidang ketenagakerjaan dengan melibatkan semua pihak yang berkepentingan/stake holder dipadukan dengan perencanaan yang tersusun berdasarkan informasi yang lengkap maka pemerintah dapat membuat suatu kebijakan ketenagakerjaan baik secara makro dan mikro sebagai strategi yang berkesinambungan.

\section{PERMASALAHAN}

Dengan masih tingginya tingkat penganggurandi Indonesia di satu sisi yang berbanding terbalik dengan upah kecil yang diperoleh pekerja/buruh menjadi sangat dilematis baik bagi pencari kerja itu sendiri maupun bagi pemerintah dan pengusaha untuk menciptakan lapangan kerja. Pertumbuhan ekonomi juga tidak cukup mampu mendongkrak penyerapan tenaga kerja yang jumlahnya dari tahun ke tahun selalu bertambah, karena itu timbul beberapa permasalahan :

1. Bagaimana perencanaan dan strategi pemerintah dalam penyediaan lapangan kerja untuk menampung tenaga kerja yang selalu bertambah?

2. Bagaimana pemerintah, pengusaha dan pekerja yang tergabung dalam dewan pengupahan merumuskan upah bagi pekerja/buruh sehingga hakhaknya untuk hidup layak terpenuhi?

3. Apakah sektor informal dapat sebagai salah satu solusi untuk mengatasi keterbatasan lapangan kerja?

\section{TUJUAN PENULISAN}

1. Untuk mengetahui perencanaan dan strategi pemerintah dalam penyediaan lapangan kerja untuk menampung tenaga kerja yang selalu bertambah.

2. Untuk mengetahui perumusan upah dari pemerintah, pengusaha dan pekerja yang tergabung dalam dewan pengupahan bagi pekerja/buruh sehingga hak hidup layak terpenuhi.

3. Untuk mengetahui sektor informal sebagai salah satu solusi untuk mengatasi keterbatasan lapang an kerja.

\section{PERENCANAAN KETENAGAKERJAAN}

Kebijakan/landasan pembangunan ketenagakerjaan diatur dalam UU RI No. 13 Tahun 2003 tentang Ketenagakerjaan (UUK) dalam Pasal 2: "Pemban- gunan ketenagakerjaan berlandaskan Pancasila dan Undang-undang Dasar Negara Republik Indonesia Tahun 1945." Mengenai asas pembangunan ketenagakerjaan diatur dalam Pasal 3: "Pembangunan ketenagakerjaan diselenggarakan atas asas keterpaduan dengan melalui koordinasi fungsional lintas sektoral pusat dan daerah."

Sedangkan mengenai tujuan pembangunan ketenagakerjaan diatur dalam Pasal 4 UUK :

a. Memberdayakan dan mendayagunakan tenaga kerja secara optimal dan manusiawi.

b. Mewujudkan pemerataan kesempatan kerja dan penyediaan tenaga kerja yang sesuai dengan kebutuhan pembangunan nasional dan daerah.

c. Memberikan perlindungan kepada tenaga kerja dalam mewujudkan kesejahteraan, dan

d. Meningkatkan kesejahteraan tenaga kerja dan keluarganya.

Walaupun menurut data Badan Pusat Statistik $(B P S)^{15}$ angka pengangguran di Indonesia hingga Februari 2013 mengalami penurunan menjadi 7,17 juta orang dibanding Agustus 2012 yang mencapai 7,24 juta orang, artinya tingkat pengangguran di Indonesia masih tinggi walaupun terjadi perbaikan ekonomi sehingga menimbulkan dampak positif bagi pertumbuhan industri. Kepala BPS Suryamin mengatakan, tingkat pengangguran terbuka Indonesia hingga Februari 2013 sebesar 5,92 persen, menurun dibandingkan tingkat pengangguran pada Agustus 2012 yang masih 6,14 persen. Begitu juga bila dibanding dengan Februari 2012 yang masih 6,32 persen.

Kondisi ketenagakerjaan di Indonesia sudah menunjukkan perbaikan baik dalam hal jumlah angkatan kerja, jumlah penduduk bekerja, dan penurunan tingkat pengangguran, kata Suryamin saat konferensi pers di kantornya, Jakarta, Senin (6/5/2013). Dari sisi jumlah angkatan kerja, pada Februari 2013 mencapai 121,2 juta orang atau bertambah 3,1 juta orang dibanding Agustus 2012, dan bertambah 780.000 orang dibanding Februari 2012. Sedangkan penduduk yang bekerja pada Februari 2013 bertambah 3,2 juta orang dibanding Agustus 2012 dan bertambah 1,2 juta orang dibanding Februari 2012.

\footnotetext{
15 http://bisniskeuangan.kompas.com/read/2013/05/06/15031042/ Turun.Tipis.Angka.Pengangguran.di.Indonesia.Capai.7.17.Juta Orang (diunduh dan diolah tanggal 23 Mei 2013)
} 
Sementara dalam hal jumlah pengangguran hingga Februari 2013 mengalami penurunan, yaitu sebanyak 70.000 orang jika dibanding Agustus 2012 dan berkurang 440.000 orang dibanding Februari 2012. "Meski jumlah angkatan kerja bertambah, tetap dalam satu tahun terakhir terjadi penurunan tingkat partisipasi angkatan kerja sebesar 0,45 persen. Tingkat partisipasi angkata kerja pada Februari 2013 sebesar 69,21 persen menurun tipis dibanding Februari 2012 sebesar 69,66 persen. Sementara bila dibanding Agustus 2012 masih cenderung naik karena masih 67,88 persen.

Sementara dalam hal lapangan kerjanya, mayoritas masih dikontribusikan dari sektor pertanian, perdagangan, jasa kemasyarakatan, dan sektor industri yang menjadi kontributor terbesar penyerapan tenaga kerja di Indonesia. Sektor-sektor lain yang menjadi kontributor penyedia lapangan kerja ini antara lain sektor perdagangan (naik 3,29 persen), sektor konstruksi naik 12,95 persen, dan sektor industri naik 4,01 persen. "Sementara sektor-sektor yang mengalami penurunan adalah sektor pertanian dan lainnya yang masing-masing mengalami penurunan 3,01 persen dan 5,73 persen," tambahnya.

Tingkat pengangguran yang berfluktuasi ini oleh Pemerintah telah dilakukan berbagai upaya antara lain: ${ }^{16}$

1. Perluasan dan penciptaan kesempatan kerja.

2. Peningkatan kualitas angkatan kerja.

3. Peningkatan informasi pasar kerja dan bursa kerja.

4. Pengendalian angkatan kerja.

5. Pembinaan hubungan industrial.

Tetapi berbagai upaya tersebut belum menunjukkan hasil yang signifikan karena laju pertumbuhan penduduk yang rata-rata $6 \%$ per tahun tidak sebanding dengan perluasan tenaga kerja yang tersedia. Lebih lanjut Erman Suparno dalam bukunya National Manpower Strategy (Strategi Ketenagakerjaan Nasional) merumuskan berbagai istilah mengenai pengangguran sebagai berikut :

Pengangguran musiman: pengangguran ini terjadi karena adanya fluktuasi kegiatan produksi barang dan jasa sebagai akibat dari fluktuasi musim.

\footnotetext{
${ }^{16}$ Erman Suparno, National Manpower Strategy (Strategi Ketenagakerjaan nasional,Jakarta:, Penerbit Buku Kompas, 2009, hal. 120.
}

Fluktuasi musim dapat terjadi karena faktor iklim atau kebiasaan masyarakat. Nelayan atau petani bisa menganggur karena musim yang berubah. Pedagang bisa menganggur karena kebiasaan masyarakat berubah untuk sementara.

Pengangguran konjungtur: pengangguran ini terjadi karena penurunan kegiatan ekonomi. Resesi ekonomi bisa mengakibatkan terjadinya pengangguran. Pengangguran disini terjadi karena berkurangnya permintaan barang dan jasa yang menyebabkan turunnya kegiatan produksi dan distribusi. Akibatnya akan terjadi pengurangan penggunaan tenaga kerja misalnya pemutusan hubungan kerja (PHK) yang selanjutnya menimbulkan pengangguran dan setengah pengangguran. Pengangguran ini akan terus terjadi sampai kegiatan ekonomi membaik.

Pengangguran teknologis: penggangguran ini terjadi karena adanya perubahan teknologi produksi yang menyangkut proses pekerjaan, jenis-jenis bahan yang digunakan, ataupun tingkat produktivitas kerjanya. Seringkali pengangguran jenis ini tidak dapat dipisahkan dengan pengangguran struktural karena penggunaan teknologi baru dapat menyebabkan perubahan dalam struktur pasar suatu perekonomian. Pengurangan pengangguran jenis ini dapat dilakukan dengan memberi latihan keterampilan kepada tenaga kerja yang terlibat dalam proses produksi sehingga datangnya teknologi baru tidak menyebabkan perubahan drastis dari penggunaan tenaga kerja.

Pengangguran struktural: pengangguran ini terjadi karena perubahan struktur pasar barang yang disebabkan karena tidak lakunya suatu komoditi tertentu di pasar akibat munculnya komoditi baru yang serupa. Pengangguran seperti ini biasa terjadi di negara sedang berkembang, sebab bisa karena struktur perekonomian yang belum maju bisa juga karena kurang bisa menciptakan lapangan kerja.

Pengangguran khusus: pengangguran ini terjadi karena adanya kelompok-kelompok khusus dalam masyarakat yang sulit mendapatkan pekerjaan seperti para penderita cacat tubuh, cacat jiwa, dan cacat sosial. Dalam kelompok ini juga termasuk mereka yang belum mempunyai keterampilan kerja, pengalaman dan mereka yang mempunyai keterbatsan tertentu (penganggur wanita) yang kerap diperlakukan secara diskriminatif. Juga termasuk dalam kelompok ini mereka yang terkena bencana alam, banjir, gempa 
bumi dan kekeringan panjang. Pengangguran karena terjadinya perang dikelompokkan dalam pengangguran politik.

Pengangguran terbuka: pengangguran terbuka (full unemployment) merupakan bagian dari angkatan kerja yang tidak bekerja atau sedang mencari pekerjaan atau sedang mempersiapkan suatu usaha atau mereka yang tidak mencari pekerjaan karena merasa tidak mungkin untuk mendapatkan pekerjaan dan mereka yang sudah memiliki pekerjaan tetapi belum mulai bekerja.

Pengangguran setengah terbuka: pengangguran setengan terbuka (under unemployment) adalah angkatan kerja yang sudah bekerja atau yang sudah membuka usaha namun waktu dan optimalisasi kerjanya belum sesuai dengan aturan kerja yang berlaku.

Dari berbagai perumusan pengertian pengangguran tersebut tentu tetap terpulang kepada pemerintah apa upaya yang telah dilakukan untuk mengatasi berbagai pengangguran tersebut. Laju pertumbuhan ekonomi ternyata tidak mampu untuk mengatasi tingkat pengangguran ini dengan segera hanya dapat menyerap sebagaian kecil saja. Beberapa upaya yang dapat dilakukan pemerintah untuk mengurangi tingkat pengangguran ini antara lain :

1. Meningkatkan spesialisasi tenaga kerja: Adam Smith ${ }^{17}$ mengatakan bahwa untuk berlangsungnya perkembangan ekonomi diperlukan adanya spesialisasi atau pembagian kerja agar produktivitas tenaga kerja bertambah. Spesialisai dalam proses produksi akan dapat meningkatkan keterampilan tenaga kerja dapat mendorong ditemukannya alat-alat atau mesin-meisn baru dan akhirnya dapat mempercepat dan meningkatkan produksi. Masih menurut Smith, pasar harus seluas mungkin agar dapat menampung hasil produksi sehingga perdagangan internasional menambah luasnya pasar yang melahirkan pasar dalam negeri dan pasar luar negeri.

2. Kualitas tenaga kerja yang rendah: rendahnya kualitas penduduk merupakan penghalang pembangunan ekonomi suatu negara. Ini disebabkan karena rendahnya tingkat pendidikan dan tingkat pengetahuan tenaga kerja. Untuk perkembangan industri jelas sekali dibutuhkan lebih banyak tenaga kerja yang mempunyai skill. Hal ini dapat dilakukan dengan memberdayakan Balai Latihan Kerja (BLK) ${ }^{18}$ yang dimiliki pemerintah sejumlah 162 tersebar di seluruh Indonesia. Beberapa BLK telah menjalankan kurikulum berbasis kompetensi kerja dan berbagai diklat di sejumlah antara lain:

a. Pertanian dan pengolahan hasil pertanian.

b. Teknologi mekanik, otomotif dan kelistrikan.

c. Bahasa, khususnya bahasa Inggris dan bahasabahasa yang dipakai untuk negara tujuan TKI.

d. Pembuatan batik, menjahit tingkat dasar dan tingkat lanjutan dan border.

e. Perhotelan, tata busana dan tata rias.

f. Pembuatan mebel, ukir kayu dan furniture lainnya.

g. Autocad, konstruksi bangunan tingkat dasar dan lanjutan, drafter, estimator dan surveyor.

3. Transmigrasi: faktor utama yang menentukan perkembangan penduduk adalah tingkat kematian, tingkat kelahiran dan tingkat perpindahan penduduk (migrasi). Salah satu agenda reformasi adalah otonomi daerah yang dianggap sebagai faktor penting dalam mengelola sumber daya pembangunan. Dengan otonomi daerah ini menjadikan transmigrasi memasuki sebuah era baru. Dengan transmigrasi persebaran penduduk termasuk tenaga kerja dapat meningkatkan kesejahteraan masyarakat dan menyebarkan kesejahteraan itu sendiri. Ada bebarapa isu penting dari program transmigrasi ini, sebagai berikut ${ }^{19}$ :

a. Berlangsungnya ketimpangan persebaran penduduk antar pulau atau antar provinsi berkenaan dengan daya tampung dan daya dukung lingkungan.

b. Terjadinya kesenjangan pertumbuhan ekonomi antar wilayah.

c. Timbulnya krisis ketahanan pangan nasional yang dalam hal ini Indonesia telah menjadi pengimpor komoditas pangan.

d. Munculnya krisis sumber daya bahan bakar minyak sehingga diperlukan energi alternatif berupa bahan bakar nabati.

\footnotetext{
${ }^{17}$ Irawan dan M. Suparmoko, Ekonomika Pembangunan, Edisi 5,Yogyakarta:BPFE, 1995, hal. 16.
} 
e. Telah dilaksanakannya keputusan politik tentang desentralisasi atau otonomi daerah.

f. Masih tingginya tingkat kemiskinan dan kelangkaan lapangan kerja atau pengangguran.

Transmigrasi harus digunakan untuk menunjang upaya penanggulangan kemiskinan dan pengangguran. Untuk menunjang perekonomian masyarakat di daerah pemerintah juga mengalokasikan belanja untuk pembangunan infrastruktur dan perbaikan sarana dan prasarana fisik seperti ja-

lan, jembatan, irigasi dan sarana lainnya yang kesemuanya itu membutuhkan tenaga kerja yang tidak sedikit. Di samping itu pemanfaatan lahan pertanian juga sangat membantu peningkatan kesehateraan masyarakat, sehingga persebaran penduduk yang dapat mengurangi kemiskinan dan pengangguran akan dapat diwujudkan.

4. Pengiriman Tenaga Kerja Indonesia (TKI) ke luar negeri: pengiriman TKI ke luar neger ${ }^{20}$ memberikan devisa yang cukup besar bagi pertumbuhan ekonomi dalam negeri disamping ikut mengatasi problem pengangguran. Secara angka devisa yang didapatkan dari kebijakan mengirm TKI ke luar negeri menempati urutan kedua setelah sektor pariwisata. Tahun 2006 devisa mencapai Rp. 60 tiriliun. Dengan perkiraan angka adakenaikan sebesar Rp. 6 tiriliun per tahun maka diperkirakan penerimaan devisa untuk tahun 2012 sebesar Rp. 96 tiriliun. Karena itu banyak pihak menyebut bahwa para TKI sebagai pahlawan devisa.

Saat ini Indonesia menempati urutan kedua setelah Filipina sebagai negara terbanyak pengirim tenaga kerja ke luar negeri. Beberapa negara penerima TKI adalah: Arab Saudi, Qatar, Kuwait, Oman, Malaysia, Singapura, Jepang dan Hongkong. Sisanyamenyebar ke beberapa negara seperti Amerika, dan beberapa negara Eropa. Tenaga Kerja Indonesia (TKI) yang bekerja di luar negeri saat ini jumlahnya sudah jutaan orang. Kepala Badan Nasional Penempatan dan Perlindungan Tenaga Kerja Indonesia (BNP2TKI) M Jumhur Hidayat mencatat setidaknya ada 6,5 juta jumlah TKI yang bekerja di 142 negara. ${ }^{21} \mathrm{Hal}$ ini sangat mendasar karena pemerintah secara umumbelum

\footnotetext{
${ }^{20} \mathrm{Ibid}$, hal. 101-102

${ }^{21}$ http://finance.detik.com/read/2013/03/14/174040/2194313/4/jumlah-tki-capai-65-juta-tersebar-di-142-negara (diunduh tanggal 23 mei 2013)
}

bisa memberikan lapangan pekerjaan yang cukup untuk warga negaranya. Bahkan pandangan ini muncul setelah para peneliti melakukan riset antara Indonesia dan Korea Selatan. Hasilnya, Korea Selatan perkembangan di sektor industrialisasi jauh lebih besar bila dibandingkan dengan Indonesia.

\section{KEBIJAKAN PENGUPAHAN}

Sebagai lembaga yang membantu Pemerintah menentukan besarnya upah pekerja/buruh Pemerintah membentuk Dewan Pengupahan sebagailembaga yang memberikan masukan kepada Pemerintah untuk menetapkan kebijakan pengupahan sebagaimana diatur dalam Pasal 88 ayat (2) UUK. Sebagai pelaksanaan ketentuan pasal tersebut maka berdasarkan Keppres No. 107 Tahun 2004 telah dibentuk Dewan Pengupahan.

Dewan Pengupahan tingkat nasional disebut Depenas, tingkat Propinsi disebut Depeprop dan tingkat Kabupaten/Kota disebut Depekab/Depeko adalah suatu lembaga non struktural yang bersifat tripartit yang keanggotaannya terdiri dari unsur pemerintah, organisasi pengusaha, serikat pekerja/serikat buruh, perguruan tinggi dan pakar. Depenas dibentuk oleh Presiden, Depeprop dibentuk oleh Gubernur dan Depekab/Depeko dibentuk oleh Bupati/Walikota.

Depenas bertugas memberikan saran dan pertimbangan kepada Pemerintah dalam rangka perumusan kebijakan pengupahan dan pengembangan sistem pengupahan nasional. Deperop bertugas:

1. Memberikan saran dan pertimbangan kepada Gubernur dalam rangka:
a. Penetapan Upah Minimum Propinsi (UMP)
b. Penetapan Upah Minimum Kabupaten/Kota (UMK) dan Upah Minimum Sektoral (UMS)
c. Penerapan sistem pengupahan di tingkat Pro- pinsi

2. Menyiapkan bahan perumusan pengembangan sistem pengupahan nasional.

Depekab/Depeko bertugas:

a. Memberikan saran dan pertimbangankepada Bupati/Walikota dalam rangka:

1) Pengusulan Upah Minimum Kabupaten/ Kota (UMK) dan/atau Upah Minimum Sektoral Kabupaten/Kota (UMSK)

2) Penerapan sistem pengupahan di tingkat Kabupaten/Kota 
b. Menyiapkan bahan perumusan pengembangan sistem pengupahan nasional.

Mengenai kebijakan pengupahan yang melindungi pekerja/buruh diatur dalam Pasal 88 ayat (3) meliputi: a. Upah minimum; b. Upah kerja lembur; c. Upah tidak masuk kerja karena berhalangan; d. Upah tidak masuk kerja karena melakukan kegiatan lain diluar pekerjaannya; e. Upah karena menjalankan hak waktu istirahat kerjanya; f. Bentuk dan cara pembayaran upah; g. Denda dan potongan upah; $h$. Hal-hal yang dapat diperhitungkan dengan upah; i. Struktur dan skala pengupahan yang proporsional;

j. Upah untuk pembayaran pesangon; k. Upah untuk perhitungan pajak penghasilan.

Untuk menentukan kebijakan pengupahan tersebut diatur dalam Pasal 89 ayat (4) komponen serta pelaksanaan tahapan pencapaian kebutuhan hidup layak sebagaimana dimaksud dalam ayat (2) diatur dengan Keputusan Menteri. Untuk pencapaian hidup layak maka Depenas, Depeprop dan Depekab/Depeko melakukan survey langsung kelapangan. Sebagai dasar hukum untuk melaksanakan survey tersebut adalah Peraturan Menakertrans (Permenakertrans) No 13 Tahun 2012 tentang Komponen dan Pelaksanaan Tahapan Pencapaian Kebutuhan Hidup Layak (KHL).

Kebutuhan untuk seorang pekerja lajang adalah 3.000 kalori per hari yang diperoleh dari komponen yang dikelompokkan ke dalam makanan dan minuman disamping kebutuhan lainnya yaitu: sandang, perumahan, pendidikan, kesehatan, transportasi, rekreasi dan tabungan. Ketujuh kelompok komponen besar tersebut diperinci ke dalam Spesifikasi Jenis Kebutuhan (Parameter Harga).

Sedangkan Kebutuhan Hidup Layak yang selanjutnya disingkat KHL adalah standar kebutuhan seorang pekerja/buruh lajang untuk dapat hidup layak secara fisik untuk kebutuhan 1 (satu) bulan. Apabila melihat besaran upah di setiap propinsi tersebut akan sulit bagi pekerja/buruh untuk dapat memepertahankan hidupnya dengan baik apalagi masih dituntut oleh perusahaan untuk meningkatkan kinerja. Berbicara upah minimum tidak sama dengan berbicara dengan Kebutuhan Hidup Layak (KHL) karena KHL tersebut adalah untuk seorang pekerja lajang. Jadi dengan jelas terlihat bahwa pekerja/buruh apabila telah berkeluarga akan semakin sulit mempertahankan hidup yang layak dengan upah yang pas-pasan tersebut.
Hampir setiap awal tahun pekerja/buruh selalu mengadakan unjuk rasa untuk memperjuangkan hakhaknya berupa upah yang cukup untuk memenuhi kehidupan yang layak (KHL). Walaupun UMP/UMK setiap tahun merupakan hasil rumusan dari Depeprop/Depekab/Depeko yang telah disahkan oleh Gubernur/Bupati/Walikota tetap saja terjadi unjuk rasa untuk memperjuangkan perbaikan dari UMP/UMK tersebut. Unjuk rasa yang dilakukan para pekerja/buruh tidak jarang yang berakhir dengan anarkis karena UMP/UMK/UMR/UMS yang telah ditetapkan akan sulit untuk dirubah artinya bahwa untuk satu tahun berlakunya upah tersebut maka si pekerja/buruh harus menerima besaran upah tersebut. Bahkan apabila tuntutan pekerja/buruh dalam unjuk rasa tidak dipenuhi perusahaan tidak jarang juga akan berakhir dengan mogok. Pemogokan ${ }^{22}$ yang pertama merupakan pemogokan yang mempunyai tujuan yang bersifat ekonomis karena menyangkut tuntutan yang berkaitan dengan perbaikan upah dan syarat-syarat kerja lainnya di dalam kerangka tatanan masyarakat yang ada. Sedangkan pemogokan yang mempunyai tujuan politis pada dasarnya dimaksudkan untuk melawan atau menjatuhkan pemerintahan yang sah.

Idealnya anggaran perusahaan yang dialokasikan untuk biaya pekerja/buruh dan biaya operasional lainnya/overhead cost adalah sebesar 30\% dari seluruh anggaran perusahaan. Dengan anggaran sebesar tersebut diharapkan tingkat kesejahteraan pekerja/ buruh akan terjamin walaupun tidak/belum dapat dikatakan kehidupan yang sejahtera. Pencapaian angka sebesar tersebut tentu harus didukung manajemen perusahaan yang tingkat efisiensinya tinggi.

\section{KETERSEDIAAN LAPANGAN KERJA}

Upah adalah hak pekerja/buruh yang diterima dan dinyatakan dalam bentuk uang sebagai imbalan dari pengusaha atau pemberi kerja kepada pekerja/buruh yang ditetapkan dan dibayarkan menurut suatu perjanjian kerja, kesepakatan atau peraturan perundangundangan termasuk tunjangan bagi pekerja/buruh dan keluarganya atas suatu pekerjaan dan/atau jasa yang telah atau akan dilakukan. ${ }^{23}$ Sudah dipaparkan diatas bahwa sesungguhnya upah yang diterima pekerja/

\footnotetext{
${ }^{22}$ Aloysius Uwiyono, Hak Mogok Di Indonesia, Jakarta: Fakultas Hukum UI, 2011, hal. 71

${ }^{23}$ Pasal 1 angka 30 UUK.
} 
buruh jauh dari kebutuhan untuk hidup layak. Upah yang diterima pekerja/buruh adalah untuk si pekerja itu sendiri tidak termasuk untuk keluarganya.

Dilema ketenagakerjaan ini semakin diperparah karena tidak jelasnya arah politik perburuhaan/ketenagakerjaan ${ }^{24}$ yang dibuat pada setiap era pemerintahan selalu berubah-ubah. Pada era reformasi ini politik perburuhan juga tidak nampak jelas terutama dalam hal penciptaan lapangan kerja. Ternyata tingkat pengangguran sebagaimana dipaparkan diatas masih cukup tinggi. Tidak cukup laju pertumbuhan ekonomi sebesar $6 \%$ untuk menyerap tenaga kerja/pengangguran 7,17 juta orang saat ini. Karena itu perlu digalakkan perluasan perekonomian sektor informal. Sektor informal ${ }^{25}$ telah diakui sebagai katup pengaman bagi tenaga kerja yang pindah dari sektor agraria tetapi tidak dapat ditampung oleh sektor industri dan merupakan motor penggerak ekonomi rakyat.

Perekonomian Indonesia memang sedang tumbuh. Namun, pertumbuhan ekonomi tersebut tidak didukung oleh pertumbuhan yang baik di sektor informal seperti Pedagang Kaki Lima (PKL). Padahal, sebesar 70\% perekonomian Indonesia ditopang oleh sektor informal. Demikian dikatakan Ketua DPD RI Irman Gusman dalam acara Musyawarah Nasio- nal Luar Biasa (Munaslub) Asosiasi Pedagang Kaki Lima Indonesia (APKLI), di Hotel Borobudur, Jakarta, Minggu (5/5/2013).

Irman Gusman mengatakan, tingginya angka sektor informal dalam perekonomian Indonesia ini juga ikut menyumbang terhadap GDP Indonesia sebesar 40\%. Ini angkanya cukup tinggi. PKL kalau dikelola dengan baik ini sebuah potensi bangsa. Terkait hal itu, pihaknya mendorong berbagai pihak untuk bisa bekerjasama mendukung keberadaan PKL sebagai bagian dari ekonomi Indonesia yang memiliki hak mengembangkan usahanya di Indonesia.

Maka dituntut hak atas ini. Kondisi di sektor formal belum mampu mendukung, makanya butuh sektor informal. Sektor formal tumbuh tapi tidak secepat tumbuhnya lapangan kerja yang dibutuhkan, ujarnya. Untuk itu, Irman berharap melalui APKLI ini bisa menjadi wadah untuk bisa mengesahkan keberadaan

\footnotetext{
${ }^{24}$ Pada jaman orde baru buruh dimanfaatkan juga sebagai kekuatan yang tergabung dalam Kesatuan Aksi Buruh Indonesia disamping kesatuan aksi lainnya, yang meminta pemerintah membubarkan PKI.

${ }^{25}$ A di Sulistiyono dan Muhammad Rustamaji, Hukum Ekonomi Sebagai Panglima,Sidoarjo: Masmedia Buana Pustaka, 2009, hal. 53.
}

PKL demi perkembangan ekonomi di sektor informal. PKL ini marketnya besar. Kenapa tidak berkembang karena tidak terorganisasi, tidak terdaftar, tidak tertib. Harapan melalui asosiasi ini, kita bisa kokoh dan disiplin agar diterima masyarakat dan berkembang, kata dia. ${ }^{26}$

Kualitas TK memang masih bermasalah. Berdasarkan Badan Pusat Statistik (BPS), total angkatan kerja per Agustus 2012 sebesar 118,04 juta jiwa, yang bekerja 110,80 juta dan mengganggur 7,24 juta jiwa. Dari jumlah tersebut pekerja tidak penuh 34,29 juta jiwa. Dari total yang bekerja, 70,51\% bekerja di sektor informal, di antaranya 5,34\% bekerja bebas di sektor pertanian. Tingginya pekerja di sektor informal menunjukkan ketidaksesuaian lapangan kerja dengan spesifikasi dan jumlah tenaga kerja. ${ }^{27}$

Walaupun pekerjaan sektor informal ini tidak selalu bersesuaian dengan tingkat keahlian yang dimiliki oleh pekerja/buruh tetapi paling tidak sektor informal sudah dapat menjawab sebagian permasalahan ketenagakerjaan yang dari tahun ke tahun selalu menjadi masalah yang sulit untuk diatasi bahkan permasalahannya cenderung terakumulasi atau tidak dapat diselesaikan pada waktu tertentu.

\section{KESIMPULAN}

Dari paparan terurai tersebut maka dapat ditarik beberapa kesimpulan sebagai berikut:

1. Pemerintah belum membuat perencanaan dan kebijakan ketenagakerjaan terutama menyangkut perluasan lapangan pekerjaan belum dilaksanakan dengan optimal, sistematis dan berkesinambungan. Hal ini terlihat dari masih tingginya tingkat pengangguran walaupun ada penurunan. Pengangguran di Indonesia hingga Februari2013 mengalami penurunan menjadi 7,17 juta orang dibanding Agustus 2012 yang mencapai 7,24 juta orang, artinya tingkat pengangguran di Indonesia tetap masih tinggi walaupun terjadi perbaikan ekonomi.

2. Secara normatif sistem pengupahan telah dirumuskan oleh Dewan Pengupahan baik tingkat nasional disebut Depenas, tingkat Propinsi disebut

\footnotetext{
${ }^{26}$ http://finance.detik.com/read/2013/05/05/142229/2238328/4/7 0pertumbuhan-ekonomi-indonesia-disumbang-sektor-informal (diunduh tanggal 23 Mei 2013)

${ }^{27}$ http://www.investor.co.id/opini/globalisasi-tenaga-kerjapertanian/60956 (diunduh tanggal 23 Mei 2013)
} 
Depeprop dan tingkat Kabupaten/Kota disebut Depekab/Depeko. Dewan pengupahan ini adalah suatu lembaga non struktural yang bersifat tripartit yang keanggotaannya terdiri dari unsur pemerintah, organisasi pengusaha, serikat pekerja/ serikat buruh, perguruan tinggi dan pakar. Tetapi upah yang dirumuskan tetap upah yang minimal bukan upah yang optimal yang dapat memenuhi kebutuhan hidup pekerja/buruh beserta keluarganya dengan layak, karena upah yang dirumuskan tersebut hanya untuk si pekerja sendiri.

3. Pekerjaan sektor informal telah menjadi salah satu solusi untuk mengatasi tenaga kerja yang menganggur. Sebesar 70\% perekonomian Indonesia ditopang oleh sektor informal. Perekonomian Indonesia ini juga ikut menyumbang terhadap GDP Indonesia sebesar 40\%. Ini angkanya cukup tinggi. Berdasarkan Badan Pusat Statistik (BPS), total angkatan kerja per-Agustus 2012 sebesar 118,04 juta jiwa, yang bekerja 110,80 juta dan mengganggur 7,24 juta jiwa. Dari jumlah tersebut pekerja tidak penuh 34,29 juta jiwa. Dari total yang bekerja, 70,51\% bekerja di sektor informal, di antaranya 5,34\% bekerja bebas di sektor pertanian.

\section{SARAN}

1. Masalah ketenagakerjaan/perburuhan sebagai salah satu unsur terpenting dari suatu proses produksi barang dan/atau jasa, pemerintah perlu membuat rumusan kebijakan dan politik perburuhan/ketenagakerjaan yang jelas dan transparan. Sehingga masyarakat khususnya para penca- ri kerja dapat mempersiapkan dirinya terhadap pekerjaan yang tersedia sesuai dengan keahlian yang dimiliki. Juga pemerintah perlu menyusun rencana/blue print ketenagakerjaan dihubungkan dengan pendidikan yang tersedia supaya terdapat sinkronisasi. Tidak terjadi penumpukan tenaga kerja karena tidak mempunyai keahlian yang sesuai dengan pekerjaan yang tersedia.

2. Upah adalah hak yang diterima pekerja/buruh untuk memenuhi kebutuhan hidupnya dan keluarganya. Upah seharusnya disusun berdasarkan kebutuhan hidup layak tidak hanya untuk pekerja/ buruhnya sendiri tetapi juga termasuk untuk keluarganya. Dan standar upah tersebut dirumuskan jangan untuk kebutuhan hidup minimal tetapi hidup yang layak sesuai dengan tingkat kehidupan di tempat pekerja/buruh berada.

3. Kemampuan pekerja informal perlu ditingkatkan dengan memberikan kesempatan yang sama dengan para pekerja/buruh formal untuk mendapatkan pelatihan yang diselenggarakan oleh pemerintah. Keberadaan pekerja/buruh informal perlu ditata dengan baik dapat hidup berdampingan dengan pengusaha formal.

\section{DAFTAR PUSTAKA}

\section{Buku:}

Sanusi Bintang dan Dahlan, Pokok-Pokok Hukum Ekonomi dan Bisinis, Bandung: Citra Aditya Bakti, 2000

Bannock, Graham, R. E. Baxter dan Evan Davis. 2004. A Dictionary of Economics. Inggris: Penguin Books Ltd

Arbi Sanit, Sistem Politik Indonesia, Kestabilan, Peta Kekuatan Politik dan Pembangunan, Jakarta: Rajawali, 1981

Sudikno Mertokusumo, Mengenal Hukum Suatu Pengantar, Yogyakarta: Liberty, 1999

Frans Magnis Suseno, Etika Politik, Jakarta: Gramedia, 1987

Erman Suparno, National Manpower Strategy (Strategi Ketenagakerjaan nasional), Jakarta: Penenrbit Buku Kompas, 2009 
Irawan dan M. Suparmoko, Ekonomika Pembangunan, Yogyakarta: BPFE, 1995,

Edisi 5 Aloysius Uwiyono, Hak Mogok Di Indonesia, Fakultas Hukum UI, 2011

Adi Sulistiyono dan Muhammad Rustamaji, Hukum Ekonomi Sebagai Panglima, Masmedia Buana Pustaka, Sidoarjo, 2009

\section{Undang-Undang:}

- Undang-Undang RI No. 13 Tahun 2003 tentang Ketenagakerjaan

- Keppres Nmor.107 Tahun 2004 tentang Dewan Pengupahan

- Permenakertrans No. 13 Tahun 2012 tentang Komponen dan Pelaksanaan Tahapan Pencapaian Kebutuhan Hidup Layak (KHL)

- Undang-Undang RI No. 13 Tahun 2003 tentang Ketenagakerjaan

- Keppres Nmor.107 Tahun 2004 tentang Dewan Pengupahan

- Permenakertrans No. 13 Tahun 2012 tentang Komponen dan Pelaksanaan Tahapan Pencapaian Kebutuhan Hidup Layak (KHL)

\section{Internet:}

- http: //hukum-on.blogspot.com/2012/06/pengertian-ekonomi-dan-hukum-ekonomi.html (diunduh tanggal 13 Mei 2013)

- http://id.wikipedia.org/wiki/Pembangunan_ekonomi (diunduh tanggal 13 Mei 2013)

- http: //bisniskeuangan.kompas.com/read/2013/05/06/15031042/Turun.Tipis.Angka.Penganggura n. di.Indonesia.Capai.7.17.Juta.Orang (diunduh tanggal 13 Mei 2013)

- http: //finance.detik.com/read/2013/03/14/174040/2194313/4/jumlah-tki-capai-65-juta-tersebardi-142- negara (diunduh tanggal 23 mei 2013)

- http://finance.detik.com/read/2013/05/05/142229/2238328/4/70-pertumbuhan-ekonomiindonesia- disumbang-sektor-informal (diunduh tanggal 23 mei 2013)

- http: //www.investor.co.id/opini/globalisasi-tenaga-kerja-pertanian/60956 (diunduh tanggal 23 Mei 2013) 